\title{
Discrimination by Heat and Proteinase Treatments between Flocculent Phenotypes Conferred on Saccharomyces cerevisiae by the Genes FLO1 and FLO5
}

\author{
By JEFFERY A. HODGSON, † DAVID R. BERRY AND \\ JOHN R. JOHNSTON* \\ Yeast Technology Laboratory, Department of Bioscience and Biotechnology, \\ University of Strathclyde, Glasgow GI $1 \mathrm{XW}, U \mathrm{~K}$
}

(Received 1 March 1985; revised 26 July 1985)

The effects of elevated temperature and of digestion with a variety of proteinases on the flocforming ability of flocculent strains of Saccharomyces cerevisiae, both genetically defined (FLOI and FLO5) laboratory and genetically undefined brewing strains, have been determined. This has permitted classification of the flocculent phenotypes of these strains according to criteria other than quantitative grading of flocculence. The flocculent phenotypes conferred by both the $F L O 1$ and the FLO5 gene were irreversibly lost upon treatment with pronase, proteinase $\mathrm{K}$, trypsin or 2-mercaptoethanol treatments. However, the floc-forming ability of cells of the FLOI strain ABXL-1D was destroyed by chymotrypsin digestion and was stable to incubation at $70^{\circ} \mathrm{C}$, whereas the floc-forming ability of cells of the $F L O 5$ strain ABXR-11A was resistant to the action of chymotrypsin and was heat labile. Tetrad analysis of a cross of these FLOI and $F L O 5$ strains indicated that the chymotrypsin and heat sensitivity phenotypes were $F L O$-gene determined. It appears that expression of the $F L O I$ and $F L O 5$ genes leads to the production of different and characteristic cell-wall proteins underlying their respective flocculent phenotypes.

\section{INTRODUCTION}

The property, termed flocculence, whereby dispersed cells of some strains of Saccharomyces cerevisiae associate to form large, rapidly sedimenting aggregates of cells at a specific stage during culture or fermentation, has received considerable attention, principally owing to the importance of this characteristic to the brewing industry (Stewart \& Russell, 1981; Johnston \& Reader, 1983). Flocculence in yeast is also of interest as an example of interaction between the surfaces of cells which is subject to control by a complex variety of genetic, environmental and metabolic factors. The aggregates formed when $S$. cerevisiae flocculates can be dissociated by sonication or by removal of $\mathrm{Ca}^{2+}$ ions, and floc formation is brought about by an incompletely understood bridging mechanism between the cell walls of flocculent strains. The bonds connecting cells in a floc are non-covalent and depend on the presence of divalent cations, $\mathrm{Ca}^{2+}$ being the most effective. Several mechanisms for flocculence have been proposed. One hypothesis is that anionic groups of cell wall components are linked by $\mathrm{Ca}^{2+}$ ions (Mill, 1964) but whether the groups are carboxyl groups of proteins (Jayatissa \& Rose, 1976; Beavan et al., 1979) or phosphate groups of phosphomannan (Lyons \& Hough, 1971) is not agreed. Another hypothesis implicates glycoproteins specific to flocculent strains acting in a lectin-like manner to cross-link the cells (Miki et al., 1982); here $\mathrm{Ca}^{2+}$ ions acting as ligands would promote flocculence by conformational changes. Flocculence is clearly a property of the cell wall of flocculent yeast strains as removal of the wall with the wall-polysaccharide-digesting enzyme Zymolyase eliminates flocculence (Miki et al., 1982) and cell-wall fragments isolated from flocculent strains show reversible and $\mathrm{Ca}^{2+}$-dependent aggregation (Amri et al., 1982;

† Present address: Department of Biochemistry, University of Glasgow, Glasgow G12 8QQ, UK. 
Nishihara et al., 1982). Treatment of flocculent cells with proteinases, protein-denaturing and protein-modifying reagents (Nishihara et al., 1977, 1982) has indicated an important role for protein components of the cell wall in the mechanism of floc formation. Polypeptides specific to cell-wall extracts from flocculent strains have been reported (Holmberg, 1978).

Singe genes, designated FLO (dominant) or flo (recessive), conferring the flocculent phenotype have been identified, most recently, after production of brewery-derived flocculent strains amenable to genetic analysis. The genes designated FLOI (Johnston \& Lewis, 1974), FLO2 (Lewis et al., 1976) and FLO4 (Stewart \& Russell, 1977), defined in brewery-derived and laboratory-bred strains, were subsequently shown to be most probably allelic (Russell et al., 1980 ) and all are now assigned to the FLOI locus, on chromosome I, $37 \mathrm{cM}$ from the adeI marker. Another gene, FLO5, normally confers a stronger degree of flocculence, and is unlinked to FLOI (Johnston \& Reader, 1983). The genes FLO1 and FLO5 behave as dominant or semidominant genes in most, but not all, crosses. A distinct recessive gene, flo 3 , has been defined (Johnston \& Lewis, 1974) and there is also evidence for tentative definition of two more recessive genes, $f l o 6$ and $f l o 7$ (R. Thornton, personal communication). Yamashita \& Fukui (1983) identified a gene designated as FLOS in a strain of Saccharomyces diastaticus (now $S$. cerevisiae) and showed it to be linked to arg4 on chromosome VIII.

Our studies on the genetics of flocculence required a characterization of the flocculent phenotype conferred on $S$. cerevisiae by $F L O$ genes more informative than grading the flocculence from weak to strong. Here we report additional characteristics of flocculence conferred by the FLOI and FLO5 genes and apply these as criteria to a number of genetically undefined flocculent strains, including some industrial production strains. This gives a classification based on the differential effects of elevated temperature and proteases on the flocforming ability of cells and permits some conclusions regarding the biochemical mechanics of FLOI and FLO5 expression.

\section{METHODS}

Strains. The strains of $S$. cerevisiae, along with their genotypes and ploidy, where known, are listed in Table 1. Enzymes. Pronase (proteinase type XIV, from Streptomyces griseus, product no. P5147), proteinase $\mathrm{K}$ (proteinase type XI, from Tritirachium album, product no. P0390), trypsin (TPCK-treated, from bovine pancreas, product no. T8642) and $\alpha$-chymotrypsin (type I-S, from bovine pancreas, product no. C7762) were obtained from Sigma, Helicase (suc d'Helix pomatia) was obtained from Reactifs IBF, France, $\beta$-glucuronidase from Boehringer Mannheim and Novozyme 234 from Novo Industri AS, Copenhagen, Denmark.

Preparation of cells. Flocculent cells were prepared by growth in $10 \%(\mathrm{w} / \mathrm{v})$ Oxoid Malt Extract or $2 \%(\mathrm{w} / \mathrm{v})$ glucose defined medium (D-glucose, $20 \mathrm{gl}^{-1}$; Difco Yeast Nitrogen Base without amino acids, $6 \cdot 7 \mathrm{~g} \mathrm{l}^{-1}$; plus any supplements required due to auxotrophic marking). The growth medium used to produce cells did not affect the results obtained. Tube cultures $(5 \mathrm{ml})$ were inoculated from fresh YPD plates (Difco Yeast Extract, Bactopeptone, D-glucose and Bacto-agar, each $20 \mathrm{gl}^{-1}$ ) to an initial $\mathrm{OD}_{600}$ of approximately $0 \cdot 1$ and grown without shaking at $20^{\circ} \mathrm{C}$ for 5 to $7 \mathrm{~d}$ until an $\mathrm{OD}_{600}$ of 2.5 to 3.0 was reached. The turbidity of highly flocculent cultures was estimated after dispersal of the flocs by washing twice with $50 \mathrm{~mm}$-EDTA, pH 7. After 5 to $7 \mathrm{~d}$ incubation the tube cultures were centrifuged at approximately $800 \mathrm{~g}$ for $5 \mathrm{~min}$ and resuspended in $5 \mathrm{ml}$ flocculation buffer $(50 \mathrm{mM}-$ sodium acetate, $3 \mathrm{~mm}^{-\mathrm{CaSO}} \mathrm{CH}_{4}, \mathrm{pH} 4 \cdot 5$ ) to assess flocculence. By means of centrifugation at approximately $800 \mathrm{~g}$ for $5 \mathrm{~min}$, followed by resuspension, the cells were washed twice in $50 \mathrm{~mm}$-sodium phosphate, $50 \mathrm{~mm}$-EDTA, pH 7.5, to disperse the flocs, and twice in water. This suspension was divided into five $1 \mathrm{ml}$ portions by dispensing into $1.5 \mathrm{ml}$ micro-centrifuge tubes. The samples were centrifuged for $1 \mathrm{~min}$ in a bench microcentrifuge, the supernatant was removed and the cells were finally resuspended in $1 \mathrm{ml}$ of the appropriate test solution.

Floc grading. A subjective estimation of flocculence was necessary owing to the large numbers of samples to be processed. Cells were removed from the test solution by centrifugation for $1 \mathrm{~min}$ in a micro-centrifuge $(12000 \mathrm{~g})$ and resuspended in $1 \mathrm{ml}$ flocculation buffer. The micro-centrifuge tubes were held up to the light, compared with appropriate controls and graded on a scale from 0 (non-flocculent) through $0 \cdot 5$ (marginally flocculent), 1 (weakly flocculent) to 4 (large flocs, rapid and complete clearing of the flocculation buffer above the sedimented cells). Quantitatively, the flocculence characteristic is a continuum but grading a flocculent cell suspension on the above scale did not affect the conclusions reached.

High temperature treatment. For treatment in the presence of $\mathrm{Ca}^{2+}$ ions, EDTA/ $\mathrm{H}_{2} \mathrm{O}$-washed cells were resuspended in flocculation buffer. When treating in the absence of $\mathrm{Ca}^{2+}$, cells could be resuspended in $50 \mathrm{mM}^{-}$ sodium acetate, $\mathrm{pH} 4.5$; or $50 \mathrm{~mm}$-sodium phosphate, $50 \mathrm{~mm}$-EDTA, $\mathrm{pH} 7.5$; or water, with no detectable 


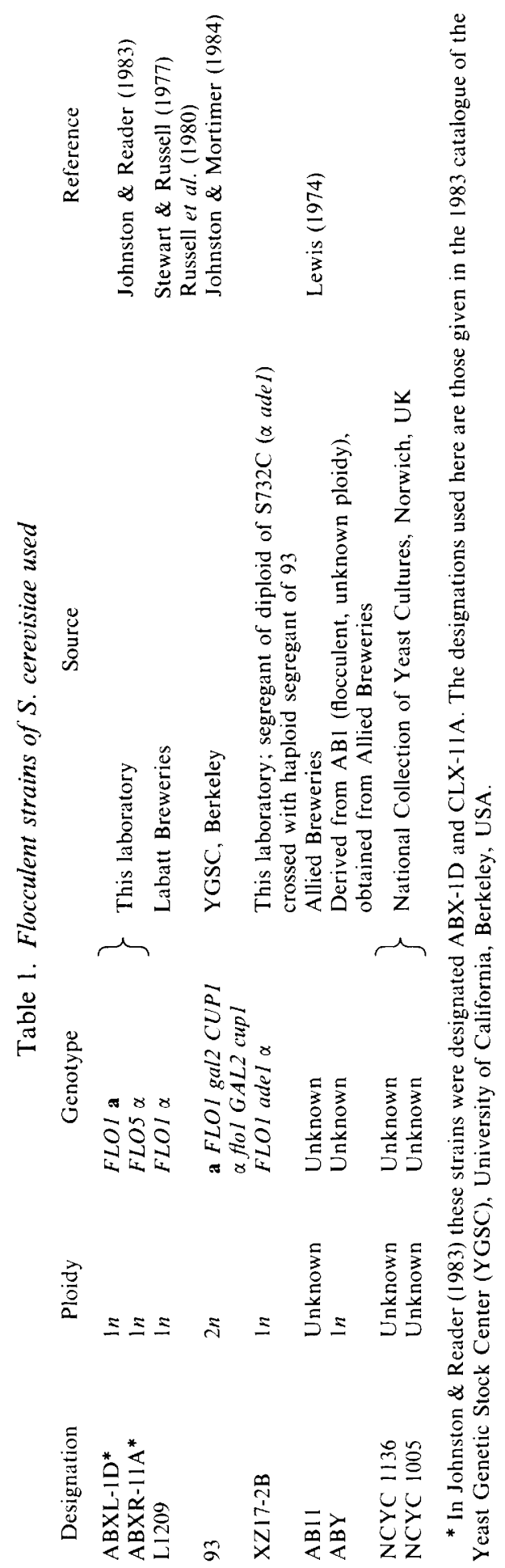


difference to the result obtained. The $1 \mathrm{ml}$ samples were immersed in a $70^{\circ} \mathrm{C}$ water-bath and at the required times spun for $1 \mathrm{~min}$ in a micro-centrifuge. After removal of the supernatant, the cells were resuspended in flocculation buffer and their flocculence was compared with controls kept in corresponding buffers at room temperature.

Treatment with proteinases. EDTA/ $\mathrm{H}_{2} \mathrm{O}$-washed cells were resuspended in $1 \mathrm{ml}$ enzyme solution and incubated at $30^{\circ} \mathrm{C}$. At required times, samples were taken, centrifuged for $1 \mathrm{~min}$ in a micro-centrifuge, and the pellet of cells resuspended in flocculation buffer for floc grading. Proteinase treatments were performed in 50 mM-sodium phosphate, $50 \mathrm{mm-EDTA}, \mathrm{pH} \mathrm{7.5}$, at the following concentrations: proteinase $\mathrm{K}, 200 \mu \mathrm{g} \mathrm{ml}^{-1}$; pronase, $200 \mu \mathrm{g} \mathrm{ml}^{-1}$; chymotrypsin, $100 \mu \mathrm{g} \mathrm{ml}^{-1}$; trypsin, $100 \mu \mathrm{g} \mathrm{ml}^{-1}$.

Genetic methods. Cell mating to produce crosses, sporulation to produce asci and ascus dissection for tetrad analysis were generally done according to procedures described by Sherman et al. (1983).

The data shown in Table 3 were obtained as follows. Colonies, grown from spores seeded into agar blocks by micromanipulation of asci digested with Helicase, were subcultured onto YPD plates and after $2 \mathrm{~d}$ at $30^{\circ} \mathrm{C}$ the resulting growth was used to inoculate $5 \mathrm{ml} 2 \%(\mathrm{w} / \mathrm{v})$ glucose defined medium. The tube cultures were incubated at $20^{\circ} \mathrm{C}$ for $7 \mathrm{~d}$ and then the tubes were centrifuged and the cells resuspended in flocculation buffer for flocculence scoring. Incubation at $70^{\circ} \mathrm{C}$ (in the presence of $\mathrm{Ca}^{2+}$ ions) and treatment with chymotrypsin were done by the procedures given above.

\section{RESULTS AND DISCUSSION}

To isolate genomic DNA from the flocculent strains ABXL-1D (FLOI) and ABXR-11A $(F L O 5)$ it was necessary to produce spheroplasts from exponential-phase cells by incubation with wall-digesting enzymes such as Helicase, $\beta$-glucuronidase of Novozyme 234 (Cryer et al., 1975). However, both ABXL-1D (FLOI) and ABXR-11A (FLO5) were substantially more resistant to digestion by such enzyme preparations compared with non-flocculent strains of $S$. cerevisiae, even after floc dispersal by washing with $50 \mathrm{~mm}$-EDTA. This resistance to digestion could have been due to a $F L O$-gene-determined protein which prevented wall-digesting enzymes gaining access to wall-polysaccharide sites. Cells of the flocculent strains ABXL-1D (FLOI) and ABXR-11A (FLO5) were subjected to high temperatures, 2-mercaptoethanol and proteinases. An increased susceptibility to wall-digesting enzymes was observed when the ability of cells to flocculate was destroyed. The best procedure was 2-mercaptoethanol treatment followed by pronase digestion. Two of the treatments eliminated the flocculence of one strain but left that of the other unaffected. These results are presented below in detail and their significance for understanding the mechanism of $F L O$-gene expression is discussed.

\section{Effects of high temperature}

Fig. 1 shows the effect of incubation at $70^{\circ} \mathrm{C}$ on the floc-forming ability of strains ABXL-1D ( $F L O I$ ) and ABXR-11A ( $F L O 5$ ). When incubated at $70^{\circ} \mathrm{C}$ in the presence of $\mathrm{Ca}^{2+}$ ions, the cells of both strains were initially in flocs. In the absence of $\mathrm{Ca}^{2+}$, cells were dispersed during the incubation. In the presence of $\mathrm{Ca}^{2+}$, the flocculence of ABXL-1D (FLOI) was apparently completely stable, whereas the floc-forming ability of ABXR-11A (FLO5) was rapidly lost despite the latter's stronger initial flocculence. Removal of $\mathrm{Ca}^{2+}$ ions by washing with EDTA buffer rendered the floc-forming ability of the FLO1 strain susceptible to heat inactivation, and led to even more rapid loss of floc-forming ability by the $F L O 5$ strain during incubation at $70^{\circ} \mathrm{C}$. Incubation of several non-flocculent strains of $S$. cerevisiae at $70^{\circ} \mathrm{C}$ did not produce any artefactual flocculence.

\section{Treatment with proteolytic enzymes}

Both pronase and proteinase $\mathrm{K}$ cleave polypeptides at a broad range of amino acyl linkages. Incubation of EDTA-dispersed cells with either enzyme had the same effect on both ABXL-1D ( $F L O 1$ ) and ABXR-11A (FLO5) cells: a rapid loss of floc-forming ability (Fig. 2).

Incubation of dispersed cells of strain ABXL-1D ( $F L O I)$ with chymotrypsin resulted in the rapid loss of floc-forming ability (Fig. 2) as was found by Nishihara et al. (1982) with the FLOI strain IF02018. However, the flocculence of strain ABXR-11A (FLO5) was remarkably resistant to the action of chrymotrypsin (Fig. 2). Since the flocculence of ABXR-11A (FLO5) was rapidly destroyed by pronase or proteinase $\mathrm{K}$ digestion, its resistance to chymotrypsin is unlikely to have been due to the inaccessibility of a wall protein mediating the flocculent 


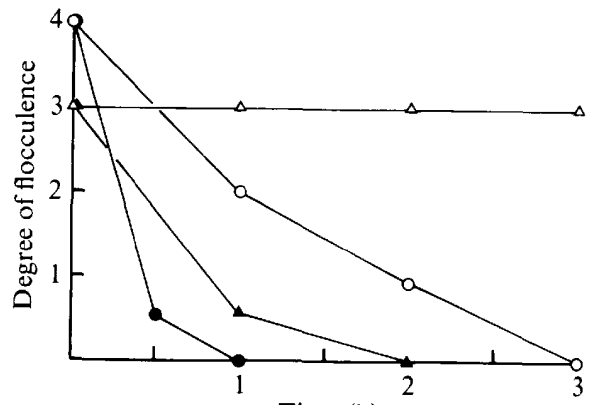

Time (h)

Fig. 1. Effect of incubation at $70^{\circ} \mathrm{C}$ on the floc-forming ability of cells of strains ABXL-1D (FLO1) and ABXR-11A (FLO5). The procedure is described in Methods. O, ABXR-11A in presence of $3 \mathrm{~mm}-$ $\mathrm{Ca}^{2+} ; \mathrm{ABXR}-11 \mathrm{~A}$ in the absence of $\mathrm{Ca}^{2+} ; \triangle, \mathrm{ABXL}-1 \mathrm{D}$ in the presence of $3 \mathrm{mM}-\mathrm{Ca}^{2+} ; \mathbf{A}, \mathrm{ABXL}-$ $1 \mathrm{D}$ in the absence of $\mathrm{Ca}^{2+}$.

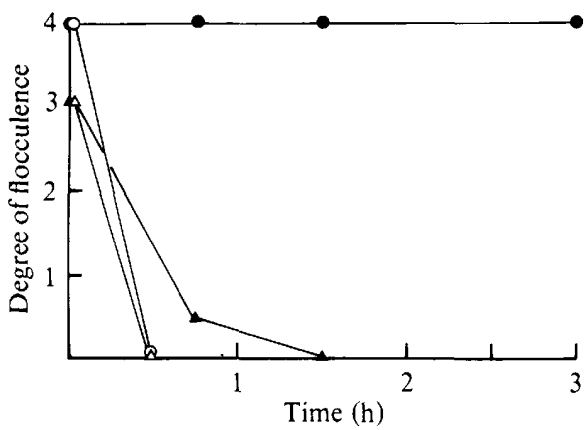

Fig. 2

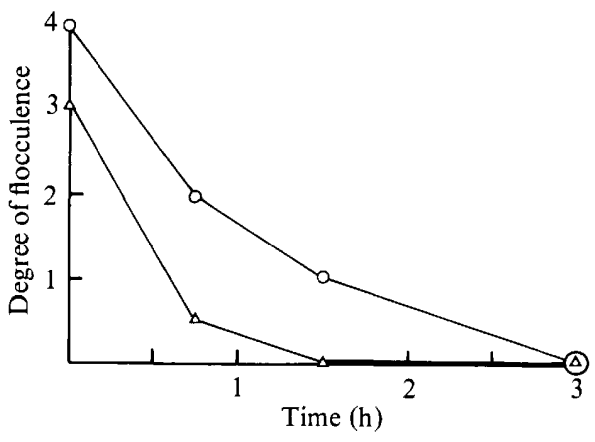

Fig. 3

Fig. 2. Treatment of cells of strains ABXL-1D (FLOI) and ABXR-11A (FLO5) with non-specific proteinases and chymotrypsin. The procedure is described in Methods. $\triangle$, ABXL-1D, pronase or proteinase $\mathrm{K} ; \boldsymbol{A}, \mathrm{ABXL}-1 \mathrm{D}$, chymotrypsin; $\bigcirc, \mathrm{ABXR}-11 \mathrm{~A}$, pronase or proteinase $\mathrm{K}$; , ABXR-11A, chymotrypsin

Fig. 3. Effect of trypsin digestion on the floc-forming ability of cells of strains ABXL-1D (FLOI) $(\triangle)$ and ABXR-IIA (FLO5) (O). The procedure is described in Methods.

phenotype conferred by the FLO5 gene. Rather, the marked difference in chymotrypsin sensitivity of the flocculating ability of ABXL-1D (FLO1) and ABXR-11A (FLO5) most probably reflected the specificity of chymotrypsin. Specifically, a wall protein essential to flocculence conferred by the $F L O I$ gene must have an accessible region containing an amino acyl linkage recognized by chymotrypsin whereas there is no such region in a protein essential for flocculence determined by the FLO5 gene. Incubation of various non-flocculent strains with chymotrypsin did not lead to any artefactual flocculence.

The floc-forming ability of cells of both ABXL-1D (FLO1) and ABXR-11A (FLO5) was lost during incubation with trypsin (Fig. 3). The rate of destruction of the flocculence of the FLO5 strain was distinctly less than that observed for the $F L O 1$ strain. For the $F L O 1$ strain, the time course of loss of floc-forming ability with trypsin was indistinguishable from that obtained with chymotrypsin digestion (Fig. 2). The differential susceptibility of the FLOI- and FLO5determined flocculating abilities to trypsin was not as marked as that found with chymotrypsin, but was observed regardless of the growth medium employed to prepare the flocculent cells $(10 \%, w / v$, malt extract, or YPD, or $5 \%, w / v$, glucose-based defined medium, or $0.1 \%, w / v$, glucose-based defined medium) or the point in the culture cycle at which the cells were harvested (mid to late exponential, early or late stationary). 


\section{Effects of other treatments}

Suspension of EDTA-dispersed cells in $0.25 \%(\mathrm{w} / \mathrm{v})$ 2-mercaptoethanol, $50 \mathrm{~mm}$-sodium phosphate, $\mathrm{pH} 7$, followed by incubation for $15 \mathrm{~min}$ at $30^{\circ} \mathrm{C}$ resulted in the irreversible loss of the floc-forming ability of both ABXL-1D (FLO1) and ABXR-11A (FLO5) cells.

Inclusion of $0 \cdot 5 \mathrm{M}-\mathrm{D}(+)$-mannose in the flocculation buffer, as described by Miki et al. (1980) resulted in reversible dispersal of both ABXL-1D and ABXR-11A flocs, whereas inclusion of $0.5 \mathrm{M}-\mathrm{D}(+)$-glucose had no such effect.

The results of the treatments with non-specific proteases, 2-mercaptoethanol and D-mannose indicate that the flocculent phenotypes conferred by the FLOI and FLO5 genes have some features in common regarding the mechanism of cross-linking between cells, including an involvement of cell wall protein and possibly carbohydrate (Miki et al., 1982) recognition. However, the results of chymotrypsin digestion and high-temperature treatment showed that the flocculent phenotypes conferred by FLOI and FLO5 can also be distinguished.

\section{Characterization of other flocculent strains}

The above results indicated a means of describing the flocculent phenotype of a strain other than by simple grading of flocculence. Fig. 4 and Table 2 show the flocculence properties of a number of other industrial and laboratory strains of $S$. cerevisiae when characterized according to the criteria described above. A spectrum of heat stabilities ranging from very heat labile (AB11 and ABY) to completely heat stable (ABXL-1D, 93, L1209) was observed (Fig. 4). Genetic analysis indicates that the FLO-gene in strain 93 is allelic to $F L O 1$ (P. de Zoysa, personal communication). Strain L1209 also carries the FLOI gene (Table 1). Table 2 summarizes the data of Fig. 4 and shows the effects of incubation with various proteases on flocculation of these strains. The flocculence of all strains was destroyed rapidly by the action of pronase and more slowly by trypsin digestion. The strains did not fall simply into the two classes of phenotype defined by ABXR-11A (FLO5) and ABXL-1D (FLOI), i.e. chymotrypsinresistant/heat-sensitive and chymotrypsin-sensitive/heat-resistant respectively, and all four combinations were observed. Strain 93 had the same chymotrypsin/heat phenotype as the ABXL-1D (FLOI) strain and NCYC 1136 had that of ABXR-11A (FLO5).

\section{Genetic analysis}

With chymotrypsin digestion and incubation at $70^{\circ} \mathrm{C}$, complete resistance or sensitivity was observed with all the strains tested; such clearly contrasting phenotypes aid classification in genetic studies. The chymotrypsin/heat phenotype of a strain may not have been $F L O$-gene determined but may have been due to the expression of other genes, responsible for components of the cell wall interacting with the $F L O$ gene product. To address this question ABXL-1D (a $F L O 1)$ was crossed with ABXR-11 A ( $\alpha F L O 5)$ since these strains had reciprocal chymotrypsin/ heat phenotypes: the flocculent phenotypes of ABXL-1D and ABXR-11A are $c^{S} t^{R}$ and $c^{R} t^{S}$ respectively (Table 3 ). Sixteen tetrads from two diploids of the cross were analysed for flocculence and the effects of chymotrypsin digestion and incubation at $70{ }^{\circ} \mathrm{C}$ (Table 3 ). The FLO1/FLO5 diploids were marginally flocculent and therefore were not treated with chymotrypsin or heat. The reason for the apparent recessive behaviour of the FLOI and FLO5 genes in these diploids is not clear.

Segregation of flocculence approximated to parental ditype:non-parental ditype:tetratype $=1: 1: 4$, confirming the independent assortment of FLOI and FLO5. The $\mathrm{c}^{\mathrm{S}} \mathrm{t}^{\mathrm{R}}$ and $\mathrm{c}^{\mathrm{R}} \mathrm{t}$ phenotypes also segregated clearly and in all three 4:0 tetrads, a 2:2 segregation of the $c^{R} t^{S}$ (FLO5 type) and the $\mathrm{c}^{\mathrm{S}} \mathrm{t}^{\mathrm{R}}$ (FLO1 type) was observed. The flocculent segregants in the $2: 2$ (flocculent: non-flocculent) tetrads most probably have a FLO1 FLO5 genotype and gave a c $\mathrm{c}^{\mathrm{R}} \mathrm{t}^{\mathrm{R}}$ phenotype. Flocculent segregants from tetrads giving 3:1 segregation of flocculence had three different chymotrypsin/heat phenotypes: $\mathrm{c}^{\mathrm{R}} \mathrm{t}^{\mathrm{S}}$ (FLO5 type), $\mathrm{c}^{\mathrm{S}} \mathrm{t}^{\mathrm{R}}$ (FLOI type) and $\mathrm{c}^{\mathrm{R}} \mathrm{t}^{\mathrm{R}}$ (presumptive FLO1 FLO5 type). Of the 16 tetrads, 14 segregated 2:2 for MATa: $M A T \alpha$, confirming the likelihood of diploidy. The remaining two tetrads segregated $3: 1$, probably due to gene conversion since both tetrads gave results with chymotrypsin and heat indicating $2: 2$ segregations for both the FLO1 and FLO5 genes. 


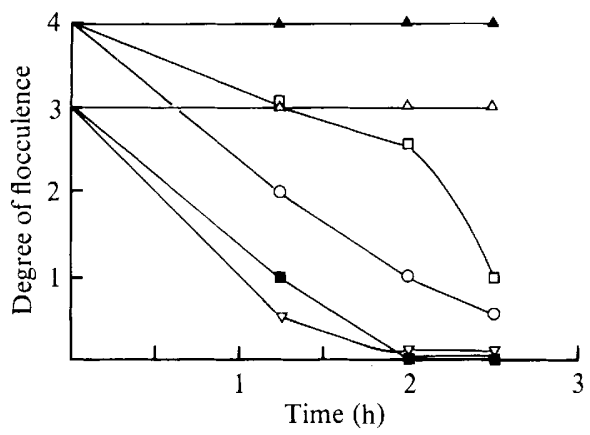

Fig. 4. Effect of incubation at $70^{\circ} \mathrm{C}$ on the floc-forming ability of various $S$. cerevisiae strains. All treatments were made in the presence of $3 \mathrm{mM}^{-\mathrm{Ca}^{2+}}$ as described in Methods. A, L1209 and 93 (identical time courses): $\triangle$, ABXL-1D; $\square$, NCYC 1136; O, ABXR-11A;, $\mathrm{AB} 11 ; \nabla, \mathrm{ABY}$.

Table 2. Characterization of the flocculence phenotype of strains of S. cerevisiae principally of unknown genotype

$\begin{array}{cccccc}\text { Strain } & \begin{array}{c}\text { Initial } \\ \text { degree of } \\ \text { flocculence }\end{array} & \begin{array}{c}70^{\circ} \mathrm{C} \\ (3 \mathrm{~h})\end{array} & \begin{array}{c}\text { Pronase } \\ (1 \mathrm{~h})\end{array} & \begin{array}{c}\text { Chymotrypsin } \\ (2 \mathrm{~h})\end{array} & \begin{array}{c}\text { Trypsin } \\ (3 \mathrm{~h})\end{array} \\ \text { ABXL-1D } & 3+ & 3+ & 0 & 0 & 0 \\ \text { ABXR-11A } & 4+ & 0 & 0 & 4+ & 0 \\ 93 & 2+ & 2+ & 0 & 0 & 0 \\ \text { XZ17-2B } & 4+ & 4+ & 0 & 0 & 0 \\ \text { L1209 } & 4+ & 4+ & 0 & 4+ & 0 \\ \text { NCYC 1136 } & 4+ & 1+ & 0 & 4+ & 0 \\ \text { NCYC 1005 } & 2+ & 0 & 0 & 0 & 0 \\ \text { ABI1 } & 3+ & 0 & 0 & 3+ & 0 \\ \text { ABY } & 3+ & 0 & 0 & 0 & 0\end{array}$

Table 3. Combined tetrad analysis data for two sporulated diploids of the cross $A B X L-1 D($ a FLOI) $\times A B X R-11 A(\alpha$ FLO5)

\begin{tabular}{|c|c|c|c|c|}
\hline \multirow{2}{*}{$\begin{array}{l}\text { Segregation of } \\
\text { flocculence } \\
(\mathrm{F} 3+: \mathrm{F}-)^{*}\end{array}$} & \multirow[b]{2}{*}{$\begin{array}{l}\text { No. of such } \\
\text { tetrads }\end{array}$} & \multicolumn{2}{|c|}{$\begin{array}{l}\text { Characterization of flocculence } \\
\text { of flocculent segregants }\end{array}$} & \multirow[b]{2}{*}{$\begin{array}{l}\text { Designati } \\
\text { of floccul } \\
\text { phenotyp }\end{array}$} \\
\hline & & $\begin{array}{c}\text { Chymotrypsin } \\
\text { digestion }\end{array}$ & $\begin{array}{c}70^{\circ} \mathrm{C} \\
\text { incubation }\end{array}$ & \\
\hline $4: 0$ & 3 & $\begin{array}{l}\mathrm{F} 3+ \\
\mathrm{F} 3+ \\
\mathrm{F}- \\
\mathrm{F}-\end{array}$ & $\begin{array}{l}\mathrm{F}- \\
\text { F- } \\
\text { F3+ } \\
\text { F3+ }\end{array}$ & $\begin{array}{l}c^{R} t^{S} \\
c^{R} t^{S} \\
c^{S} t^{R} \\
c^{S} t^{R}\end{array}$ \\
\hline $3: 1$ & 11 & $\begin{array}{l}F- \\
\text { F3+ } \\
\text { F3+ }\end{array}$ & $\begin{array}{l}\mathrm{F} 3+ \\
\mathrm{F} 3+ \\
\mathrm{F}-\end{array}$ & $\begin{array}{l}c^{S} t^{R} \\
c^{R} t^{R} \\
c^{R} t^{S}\end{array}$ \\
\hline $2: 2$ & 2 & $\begin{array}{l}\mathrm{F} 3+ \\
\mathrm{F} 3+\end{array}$ & $\begin{array}{l}\text { F3+ } \\
\text { F3+ }\end{array}$ & $\begin{array}{l}c^{R} t^{R} \\
c^{R} t^{R}\end{array}$ \\
\hline $\begin{array}{l}\text { rents of cross: } \\
3 X L-1 \mathrm{D}(\mathrm{a} F L O I) \\
3 \mathrm{XR}-11 \mathrm{~A}(\alpha F L O 5)\end{array}$ & & $\begin{array}{l}\mathrm{F}- \\
\mathrm{F} 3+\end{array}$ & $\begin{array}{l}\mathrm{F} 3+ \\
\mathrm{F}-\end{array}$ & $\begin{array}{l}c^{S} t^{R} \\
c^{R} t^{S}\end{array}$ \\
\hline
\end{tabular}

* F3+, strongly flocculent; $\mathrm{F}-$, non-flocculent.

$+c^{S} / c^{R}$, flocculence sensitive/resistant to the action of chymotrypsin; $t^{S / t^{R}}$, flocculence labile/stable to incubation at $70^{\circ} \mathrm{C}$ for $3 \mathrm{~h}$ in the presence of $3 \mathrm{mM}-\mathrm{Ca}^{2+}$. 
The results of tetrad analysis indicated that when a haploid segregant carries a FLOI and a FLO5 gene, both the $\mathrm{c}^{\mathrm{R}}$ phenotype of FLO5 and the $\mathrm{t}^{\mathrm{R}}$ phenotype of FLO1 are observed. Sequential application of chymotrypsin digestion and $70^{\circ} \mathrm{C}$ incubation, in either order, eliminated the flocculence of $c^{R} t^{R}$ segregants. These results suggest that simultaneous expression of FLOI and FLO5 genes is possible in the same haploid cell. Thus although chymotrypsin digestion eliminates a component of the cell wall conferred by $F L O 1$, a protein conferred by FLO5 remains unaffected and enables the cells to form flocs. Similarly, hightemperature treatment denatures only the $F L O 5$-determined protein associated with the cell wall, while the $F L O 1$-determined proteins remains native. An implication of the segregation of the $c^{S_{1}} t^{R}$ and $c^{R} t^{S}$ phenotypes is that in each of the strains ABXL-1D and ABXR-11A these phenotypes are conferred by one gene, which is almost certainly their respective $F L O$-gene.

Previous results of tetrad analysis of FLOI $\times$ FLO5 crosses have provided evidence that FLOI and FLO5 are distinct genes (Johnston \& Reader, 1983). The results here show that the $F L O I$ and FLO5 genes can be distinguished by means other than a quantitative scoring of the flocculence they confer and their chromosomal locations. It appears that the expression of the FLOI and FLO5 alleles results in the production of different and characteristic cell wall located proteins which are responsible or at least required for their flocculent phenotypes. The cell wall located proteins coded for by the FLOI and FLO5 alleles in ABXL-1D and ABXR-11A differ in their stability to thermal denaturation and the presence of a region of polypeptide susceptible to cleavage by chymotrypsin. Our results exclude models for the mechanism of flocculence which propose that the modification to the cell wall of flocculent cells is the same whether the $F L O 1$ or the FLO5 gene confers the flocculence. Proteins mediating flocculence determined by different alleles at the same $F L O$ locus could have different phenotypes with respect to chymotrypsin and high temperature, for example the FLOI allele in L1209 is $\mathrm{c}^{\mathrm{R}}$. This could be due to a difference in gene sequence, or the interaction of other genes. These new descriptions of phenotypes conferred by genes $F L O 1$ and FLO5 may significantly assist genetic studies of flocculence, by enabling particular $F L O$-genes carried by segregants of crosses to be identified. It may also be possible to assess the effects of different genetic backgrounds on $F L O$ gene expression and interactions between different $F L O$-genes.

We wish to thank Christine Daubney and Lynn Anderson for technical assistance and Priyal de Zoysa for helpful discussions. The support of SERC (Biotechnology Directorate) Grant C19141 to Drs J. R. Johnston and D. R. Berry is gratefully acknowledged.

\section{REFERENCES}

Amri, M. A., Bonally, R., Duteurtre, B. \& Moll, M. (1982). Yeast flocculation: influence of nutritional composition on cell wall composition. Journal of General Microbiology 128, 2001-2009.

Beavan, M. J., Belk, D. M., Stewart, G. G. \& Rose, A. H. (1979). Changes in electrophoretic mobility and lytic enzyme activity associated with development of flocculating ability in Saccharomyces cerevisiae. Canadian Journal of Microbiology 23, 68-74.

Cryer, D. R., Eccleshall, R. \& Marmur, J. (1975). Isolation of yeast DNA. Methods in Cell Biology 12, 39-44.

HOLMBERG, S. (1978). Isolation and characterisation of a polypeptide absent from non-flocculent mutants of Saccharomyces cerevisiae. Carlsberg Research Communications 43, 401-413.

Jayatissa, P. M. \& Rose, A. H. (1976). Role of wall phosphomannan in flocculation of Saccharomyces cerevisiae. Journal of General Microbiology 96, 165174.

Johnston, J. R. \& Lewis, C. W. (1974). Genetic analysis of flocculation in Saccharomyces cerevisiae and tetrad analysis of commercial brewing and baking yeasts. In Second International Symposium on the Genetics of Industrial Microorganisms, pp. 339 355. Edited by K. D. MacDonald. London: Academic Press.

Johnston, J. R. \& MoRtimer, R. K. (1984). Pedigree of the Yeast Genetic Stock Center 'wild-type' strains S288C and X2180 of S. cerevisiae. Heredity 52, 459.

Johnston, J. R. \& Reader, H. P. (1983). Genetic control of flocculation. In Yeast Genetics: Fundamental and Applied Aspects, pp. 205-224. Edited by J. F. T. Spencer, D. M. Spencer \& A. R. W. Smith. New York: Springer-Verlag.

LEwIS, C. W. (1974). Genetic and related aspects of flocculation in yeast. PhD thesis, University of Strathclyde, Glasgow.

Lewis, C. W., Johnston, J. R. \& Martin, P. A. (1976). The genetics of yeast flocculation. Journal of the Institute of Brewing 82, 158-160.

Lyons, T. P. \& Hough, J. S. (1971). Further evidence for the cross-bridging hypothesis for flocculation of brewer's yeast. Journal of the Institute of Brewing 77, 300-305. 
MiLl, P. J. (1964). The nature of the interactions between flocculent cells in the flocculation of Saccharomices cererisiae. Journal of General Microbiology 35, 61-68.

Miki, B. L. A., Poon, N. H., James, A. P. \& Seligy, V. L. (1980). Flocculation in Saccharomyces cererisiae: mechanism of cell-cell interaction. In Current Developments in Yeast Research, pp. 165-170. Edited by G. Stewart \& I. Russell. Toronto: Pergamon Press, Canada.

Miki, B. L. A., Poon, N. H. \& Seligy, V. L. (1982). Repression and induction of flocculation interactions in Saccharomyces cerevisiae. Journal of Bacteriology 150, 890-899.

Nishihara, H., Toraya, T. \& Fukui, S. (1977). Effect of chemical modification of cell surface components of a brewer's yeast on the floc-forming ability. Archices of Microbiology 115, 19-23.

Nishihara, H. Toraya, T. \& Fukui, S. (1982). Flocculation of cell walls of brewer's yeast and effects of metal ions, protein-denaturants and en- zyme treatments. Archices of Microbiology 131, 112115.

Russell, I., Stewart, G. G., Reader, H. P., JOHNSTON, J. R. \& MARTIN, P. A. (1980). Revised nomenclature of genes that control yeast flocculation. Journal of the Institute of Brewing 86, 120-121.

Sherman, F., Fink, G. R. \& Hicks, J. B. (1983). Methods in Yeast Genetics. Cold Spring Harbor, New York: Cold Spring Harbor Laboratory.

Stewart, G. G. \& Russell, I. (1977). The identification, characterization and mapping of a gene for flocculation in Saccharomyces sp. Canadian Journal of Microbiolog! 23, 441-447.

Stewart, G. G. \& Russell, I. (1981). Yeast flocculation. In Brewing Science, vol. 2, pp. 61-92. Edited by J. R. A. Pollock. London: Academic Press.

Yamashita, I. \& Fukui, S. (1983). Mating signals control expression of both starch fermentation genes and a novel flocculation gene FLOS in the yeast Saccharomyces. Agricultural and Biological Chemistry 47, 2889-2896. 